\title{
Mesenteric Neural Stem Cell for Chronic Spinal Cord Injury: A Literature Review
}

Tjokorda Gde Bagus Mahadewa ${ }^{1 *}$, Putu Eka Mardhika ${ }^{1}$, Steven Awyono ${ }^{1}$, Made Bhuwana Putra ${ }^{1}$, Glen Sandi Saapang ${ }^{1}$, Kadek Dede Frisky Wiyanjana ${ }^{1}$ (D), Kevin Kristian Putra ${ }^{1}$, Tjokorda Istri Sri Dalem Natakusuma ${ }^{2}$, Christopher Ryalino ${ }^{3}$ (D)

${ }^{1}$ Division of Neurosurgery, Department of Surgery, Faculty of Medicine, Universitas Udayana, Bali, Indonesia; ${ }^{2}$ Postgraduate Program, Faculty of Medicine, Universitas Udayana, Bali, Indonesia; ${ }^{3}$ Department of Anesthesiology and Intensive Care, Faculty of Medicine, Universitas Udayana, Bali, Indonesia

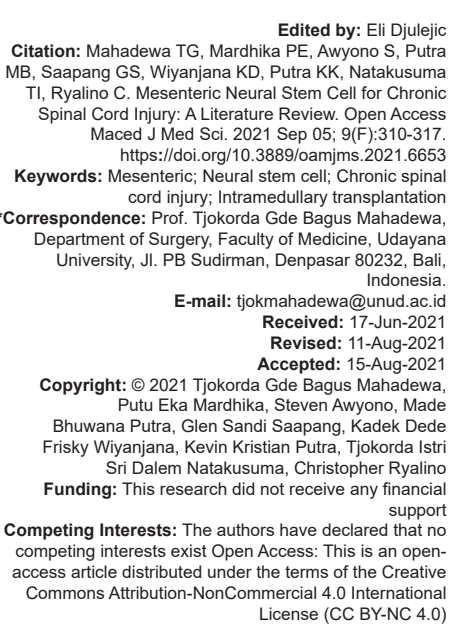

\begin{abstract}
Spinal cord injury $(\mathrm{SCl})$ is a common and potentially life-threatening condition with no established treatment to treat the primary injury. Mesenteric neural stem cell (NSC) therapy is a promising stem cell therapy to treat primary $\mathrm{SCl}$ in the chronic phase. We aimed to review the literature narratively to describe current evidence regarding mesenteric NSC in SCl. Primary SCl refers to tissue damage that occurs at the time of trauma that leads to the death of neuronal cells. In chronic SCl, the ability of neuronal regeneration is compromised by the development of gliotic scar. NSC is a stem cell therapy that targeted SCI in the chronic phase. Enteric NSC is one of the sources of NSC, and autologous gut harvesting in the appendix using endoscopic surgery provides a more straightforward and low-risk procedure. Intramedullary transplantation of stem cell with ultrasound guiding is administration technique which offers longterm regeneration. Mesenteric NSC is a promising stem cell therapy to treat chronic SCI with low risk and easier procedure to isolate cells compared to other NSC sources.
\end{abstract}

\section{Introduction}

Spinal cord injury (SCl) is a potentially lifethreatening condition and requires a high long-term treatment cost. It commonly occurs in young adult and traffic accidents; falls from height, violence, and sportassociated injury are the common cause of injury [1]. The pathophysiology of $\mathrm{SCl}$ is very complicated, consisting of primary, secondary, and tertiary injuries. Primary injury is the injury caused directly by the trauma itself, while the secondary and tertiary injury is the effects of physical and biochemical responses against the primary injury [2]. At present, the established treatment for $\mathrm{SCl}$ is focusing on preventing secondary and tertiary injury. There is no established treatment to treat the primary injury. Therefore, the development of more effective treatments, or better yet, cures for $\mathrm{SCl}$, is of paramount importance.

Stem cell therapy is a promising therapy to replace death cells due to primary injury of $\mathrm{SCl}$. The use of several stem cell sources for $\mathrm{SCl}$ therapy has been attempted with varying degrees of success, including non-neural lines. A variety of stem cell sources have shown great potential toward achieving partial, if not complete, functional recovery following $\mathrm{SCl}$.

Enteric neural stem cells (ENSCs), isolated from the adult gut, are a promising alternative stem cell source. These are the resident stem cells of the ENS and have been isolated from patients up to 80 years [3]. They are derived from neural crest cells (NCCs), a transient population of cells that give rise to numerous cell types throughout the body, including the ENS of the gastrointestinal tract [4]. Transplantation of these cells into the gastrointestinal tract shows that they can differentiate into neurons and glial cells [5]. Recently, ENSCs cultured from postnatal human tissue have been shown to retain similar migratory, proliferative, and differentiation capabilities to embryonic neural crest-derived cells, demonstrating their potential benefits toward tissue regeneration in $\mathrm{SCl}$ following transplantation [6]. In this article, we describe the pathophysiology of $\mathrm{SCl}$ and its relation to the concept of 
stem cell therapy in SCI. Following that, we discussed the ENSCs as potential NSCs to treat SCI.

\section{$\mathrm{SCl}$ and Pathophysiology}

The main issue regarding the pathophysiology of $\mathrm{SCl}$ is tissue damage [7]. Following $\mathrm{SCl}$, tissue injury is divided into two main phases, primary and secondary injury [8]. Primary injury refers to tissue damage that occurs at the time of trauma that leads to the death of neuronal cells. A secondary injury is a progressive event that happens after primary injury and lasts for a few weeks, months, or years. Several temporal phases of $\mathrm{SCl}$ can be divided into five categories depending on time relative to the primary injury. Chronic $\mathrm{SCl}$ is classified as an injury that is occurred within 6 months after the primary injury that has the potential either functional or structural plasticity of the spared spinal cord [2], [9].

Many theories explain secondary injury in $\mathrm{SCl}$, such as apoptosis, ischemia, excitotoxicity, inflammation, mitochondrial dysfunction, and oxidative cell damage similar to traumatic brain injury [2]. Endogenous repair processes aim to isolate the lesion to expand and clear necrotic tissue. The repair process involves inflammation, infiltration of leucocyte, glial scar formation (astrogliosis), and programmed cell death [10]. Uncontrolled activity of these secondary mediators leads to the exacerbation of the injury, creating an inhibitory chemical and physical milieu that prevents endogenous efforts of remyelination, plasticity, regeneration, and repair. The mature central nervous system (CNS) is incapable of neurogenesis. However, the study found a localization in which neurogenesis was active around the subgranular and subependymal layers of the hippocampus.

One of the mechanisms in chronic SCl was the development of gliotic scar and cerebrospinal fluid (CSF) accumulation inside the spinal cord caused "fluidfilled cavities," also called syringomyelia (Figure 1) [11]. Traumatic syringomyelia develops for about $4.5 \%$ of patients with $\mathrm{SCl}$ [12]. Many theories tried to explain the pathogenesis of syringomyelia, such as intramedullary pulse pressure proposed by Greitz [12]. Nowadays, the theory explaining syringomyelia resulted from abnormal CSF hydrodynamics within the subarachnoid space of the spinal caused by spinal trauma leads to the ischemic lesion and spinal cystic degeneration, thus forming a larger cavity. Other theories explain that atrophy of the spinal cord will force the central canal to expand, force spinal cord parenchyma outward, and disturb CSF hydrodynamic circulation. CSF cannot circulate within the central canal and would prefer to enter spinal cord parenchyma and form "fluid-filled cavity." Diffuse obstruction of the subarachnoid space may also induce syringomyelia [13].

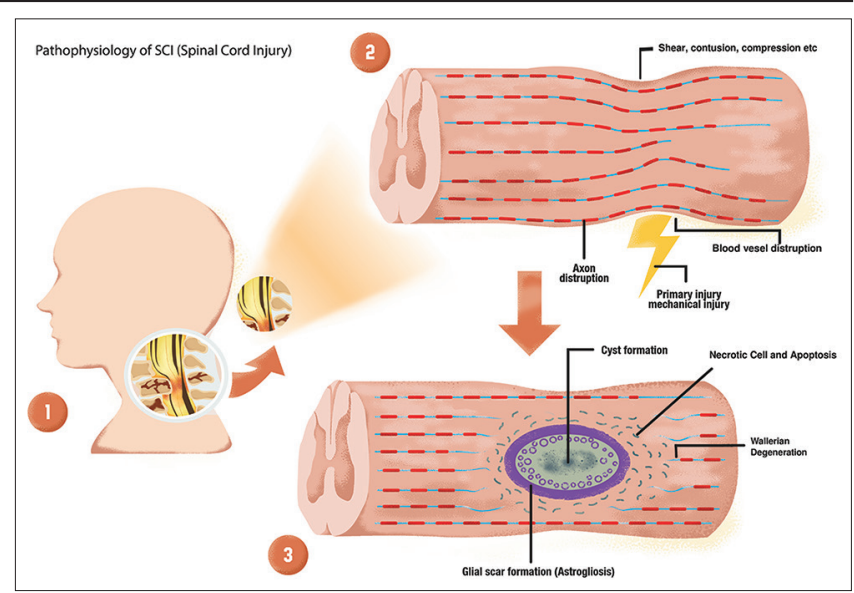

Figure 1: Schematic pathophysiology of spinal cord injury (SCI) and development of gliotic scar, which compromises the axonal regeneration in $\mathrm{SCl}$

The presence of gliotic scar and traumatic syringomyelia inhibits the growth of axons through the lesional tissue. This problem is challenging because the gliotic scar is one of the endogenous repair mechanisms of $\mathrm{SCl}$ while it also inhibits the growth of transplanted stem cells. Efforts should be made to degrade the gliotic scar to improve the growth of axons through lesional tissue.

\section{Concept of Stem Cell Therapy in SCI}

The strategy of stem cell transplantation in $\mathrm{SCl}$ is executed based on the phase of the $\mathrm{SCl}$ itself. As we know, there are immediate, acute, subacute, and chronic phases of $\mathrm{SCl}$. The goals of stem cell treatment are different according to the phase of $\mathrm{SCl}$. In the immediate phase, the goal is reducing cell death due to trauma, while in the acute phase, the goal is increasing neuroprotection. In the subacute phase, the goal is tissue modification, and in the chronic phase, the target of stem cell treatment is cell repair through neuroplasticity [10].

At present, several sources of cells have been studied for the treatment of SCl, including mesenchymal stem cells (MSCs), peripheral myelinated cells (PMCs), and NSCs. The sources of MSCs are bone marrow stromal cells, umbilical cord blood, and umbilical cord matrix cells. The PMCs are originating from ensheathing olfactory cells and Schwann cells. The source of NSCs comes from adult and fetal tissue, embryonic stem cells (ESCs), or induced pluripotent stem cells (iPSCs) (Figure 2) [10].

Transplantation of $\mathrm{MSCs}$ in $\mathrm{SCl}$ results in immunomodulation and trophic support in injured $\mathrm{SCl}$, which caused an increase in endogenous neuron regeneration [14]. However, MSCs did not produce new neurons to replace the loss of neurons due to injury. 


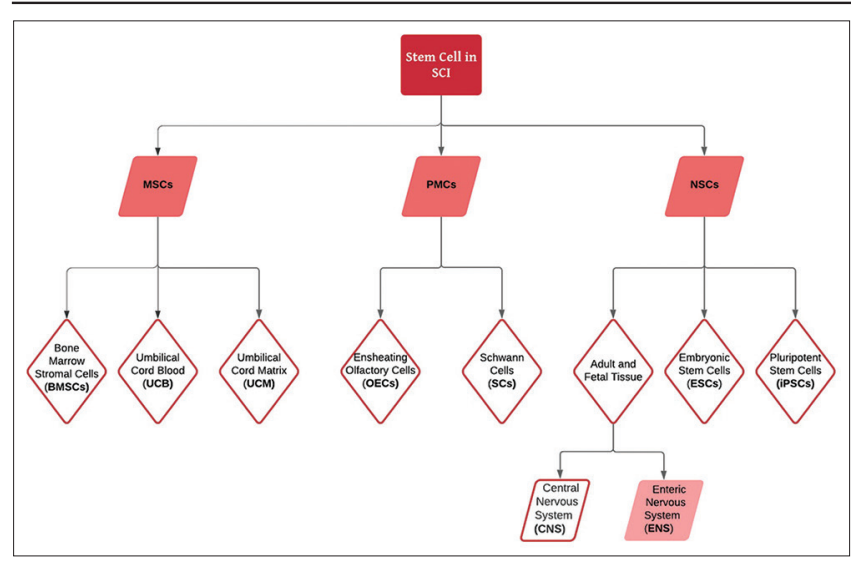

Figure 2: Schematic diagram of stem cell therapy sources for spinal cord injury treatment

Transplantation of PMCs plays a role in remyelination and tissue scaffolding. It is reported that transplantation of PMCs has resulted in improved motor and sensory function [15]. However, the source of these cells is from an isolated area of the brain and must be removed surgically, which presents a high additional risk to the patient [10].

The transplantation of NSCs provides regeneration through cell replacement and neuroplasticity (Figure 3). As known, multipotent NSCs are located in the periventricular regions of the CNS, especially the lining of the ventricles. In particular, the NSCs are from the ependymal layer in the subventricular and subgranular zones of the brain and the subependymal layer of the central canal in the spinal cord [10]. Another source of NSCs is the ESCs. The ESCs line is very versatile and easily differentiates into many germ cells of the mesoderm, endoderm, and neuroectoderm. However, the versatility and ability to differentiate into many cell lines provide another problem. The main concern of ESCs transplantation is the risk of tumor formation and immune rejection. One of the undifferentiated features of ESCs is their ability to form teratomas and has been shown to activate the innate immune response.

Advance in technology gives rise to advancement in iPSCs technology and have opened

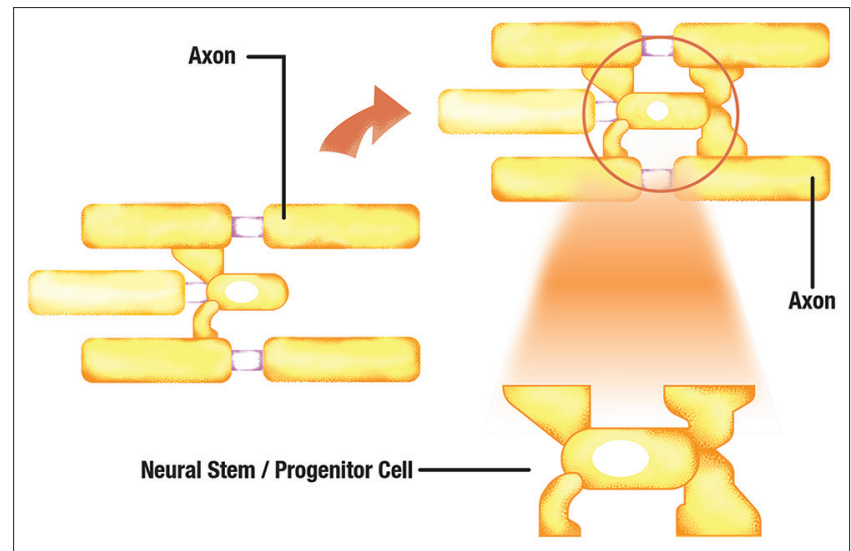

Figure 3: Schematic picture describing role of neural stem cell in cell regeneration during chronic spinal cord injury up new potential therapeutic approaches. The iPSCs line is created by returning somatic cells to a pluripotent state through upregulation of four transcription factors, which are OCT4 and SOX2, with KLF4 and C-MYC. However, the reprogramming method is still inefficient and requiring more than 6 months for manufacture and differentiation to produce a patient-specific product [10].

\section{ENSC}

In adults, NSCs have been restricted to specific areas in the subventricular zone of the lateral ventricles and the subgranular zone of the dentate gyrus of the hippocampus [16], [17]. Harvesting and isolation of CNS-derived NSCs from adults are only possible through highly invasive surgery or under surgical indications. This kind of procedure is a highrisk procedure, which precludes their use for clinical translation [10].

At present, the NSCs can be harvested and isolated from the peripheral nervous system (PNS), which reduces the risk of cell harvesting and isolation. The enteric nervous system (ENS) is the part of the PNS that controls critical aspects of bowel function, including peristalsis, regulation of blood flow, and secretion of water and electrolytes. The adult ENS consists of neurons and glial cells arranged as ganglia in two concentric rings, the myenteric and submucosal plexus, which lie between the layers of smooth muscle [18].

ENSCs are persistent ENS stem cells isolated from the intestine of an adult [3]. ENSCs originate from NCCs that migrate from the vagal and sacral nerve tubes that colonize the developing intestine [18], [19]. Progressive differentiation from the stem cells into neurons and glial cells and further organization into ganglia occur in the intestine environment [20]. ENSCs have been shown to maintain similar migration, proliferation, and differentiation capabilities to cells derived from embryonic nerve crest. These capabilities are demonstrating their potential benefits to neural tissue regeneration [6].

As we mentioned above, the goal of stem cell treatment in chronic $\mathrm{SCl}$ is regeneration through neuroplasticity. Plasticity is the ability of the nervous system to rewire its connection or adapt its functions to the actual microenvironmental situation [21]. ENS expressed growth-associated protein 43, which is a protein that is correlated to neuronal growth and regeneration. This protein is highly expressed in the myenteric and submucous ganglia, thus giving evidence for a lifelong capability of the ENS to adapt to new challenges [22].

The characteristic of ENS and CNS must be similar to permit ENSCs to be successfully transplanted 
in the injured spinal cord. Although functionally and morphologically different, both CNS and ENS share many similar essential characteristics. The ENS and CNS are connected physically and in constant communication through the gut-brain axis. Higher brain centers exert control to the intestine through either vagal pathways, sympathetic pathways, or pelvic pathways. Communication between ENS and CNS is bidirectional, with axons of ENS projecting to the spinal cord [23]. The close interaction and information transfer between CNS and ENS strongly suggest that transplanted ENSCs would be able to integrate with endogenous spinal cord neurons to restore function.

Another factor that can assess the similarity between CNS and ENS is the expressed protein by progenitor cells in CNS and ENS. Neurotrophin receptor p75 is expressed in stem cells found at the subventricular zone and the progenitor cell retrieved from the submucosal and myenteric plexus of the intestine [24]. The other marker expressed in CNS and ENS is SRY-box-2 (Sox2). Sox2 is an essential protein in maintaining pluripotency by suppressing transcription factors that guide NSC to differentiate. Sox2 is also taking part in the neurogenesis of progenitor cells [25]. A cell that expresses a high level of Sox2 has been shown to maintain self-regeneration capacity and produce a neurosphere [26].

The other important marker that is commonly used to identify the NSC population is nestin. Nestin is a filament protein that is important in sustaining the life of NSC. When removed, the NSC without nestin will increase the apoptotic process and decrease selfrenewal potency. Both ENS and CNS progenitor cells highly expressed nestin [27], [28], [29].

Another study also reported that the differentiation of NSCs into neuron or glial cells resulted in identical expression of protein from the neuron, oligodendrocyte, and astrocyte in both CNS and ENS. The identical expressed proteins in the neuron are Tuj1, PGP9.5, nNOS, and neurofilament, while GFAP and S100 are the protein identically expressed by glial cells in both CNS and ENS [30], [31], [32].

Besides expressing similar progenitor protein, neurotransmitters utilized by cells in ENS must be similar to CNS. In the literature, the ENS also utilizes almost all the neurotransmitters similar to the CNS [33]. However, the level of several neurotransmitters is different between the spinal cord and intestine. The neurotransmitters are acetylcholine, serotonin, gamma-aminobutyric acid, nitric oxide, nNOS, and glutamate [33], [34]. Levels of nNOS, serotonin, glutamine, and acetylcholine were reportedly similarly high between the spinal cord and intestine. Expression of neurotransmitter GABA was significantly higher in the spinal cord compared to the intestine [34]. Neurons of the myenteric plexus produce serotonin but in more modest quantities [35].
The bidirectional communication between ENS and CNS, followed by similar protein expression and neurotransmitters, suggests that both nervous systems have similar characteristics. The transplantation of ENSCs into the injured spinal cord is possible because of this similarity. It is reported that ENSCs readily differentiated toward a neuronal phenotype both in vitro and in vivo following transplantation. The neuronal phenotype showed a high expression of Tuj1, which is a neuronal marker. The transplanted ENSCs were reported expressed Tuj1+, which suggest a potential source to replace neuron in $\mathrm{SCl}$ [34].

The transplanted ENSCs have the ability to extend axons alongside spinal cord-derived cell axons to function as bridges. This is supported by the extension of axons toward one another leads to the formation of synaptic junctions. The GFP+ staining within the injury zone overlapped with endogenous Tuj1+/GFP- staining, showing a synergistic relationship between the spinal cord and the transplanted cells, which encourage survival through the formation of "bridges." Transplanted ENSCs appeared to cross the glial scar demonstrating differentiation to appropriate lineage. They did not seem to cause overtly increased activation or proliferation of astrocytes or macrophages/ microglia [34].

\section{Autologous Gut Harvesting}

Autologous gut harvesting must be performed to obtain ENSCs. Theoretically, all the gastrointestinal systems can be harvested to obtain ENSCs. However, we should consider the risk and benefit regarding the location of autologous gut harvesting. The appendix is a good site that can be used for harvesting ENSCs [36]. Appendix does not have any essential function to human physiology, and it is located in an easily accessible area. Appendectomy is not harmful, even in a diseased patient, and with minimally invasive surgical techniques, the patient's risk is decreased further. Adult ENS can be repeatedly accessed through routine endoscopy to generate an autologous cell source for transplant, thus avoiding the harvesting/ethical issues that hinder other NSC sources.

Cells derived from dissociated gut tissues can be cultivated and expanded. This process will be giving rise to neurons and glial cells [37]. These cells not only have proliferation and differentiation potential but are also capable of migrating [38]. The techniques developed to isolate ENS progenitors involve selection on the basis of cell surface marker expression, culture with factors favoring progenitor cell growth, or selection on the basis of proliferative potential [37], [39].

Co-cultivation of ENSs with mesenteric vascular cells (MVCs) facilitates neuronal regeneration 
and tube formation [40]. The generated neurospheres and dissociated cells showed characteristics of NSCs shown by expression of nestin, Nanog, Sox2, and Oct4. The differentiating and mature neurons are also shown by the expression of $ß$-Tubulin III and tyrosine hydroxylase [41].

As described by Hagl et al. [41], after separation of submucous and muscular layer, the tissue is digested enzymatically with collagenase Il solution (Worthington) for $4 \mathrm{~h}$. Isolation of pure myenteric (MP) and submucous plexus was performed, and the collected ganglia were mildly dissociated with Accutase for $20 \mathrm{~min}$ and plated in $25 \mathrm{~cm}^{2}$ culture flasks at standardized densities $(16,106$ cells/flask) using a standard neuronal medium. After 6 days in vitro, freefloating enteric neurospheres (EnNSs) abounded while differentiating neurons and glia cells at the bottom could easily be discriminated. The supernatant with EnNSs and differentiation neuronal and glial cells was cultivated further. The EnNSs cultures were maintained up to 40 days at $37^{\circ} \mathrm{C}$ in a humified atmosphere.

\section{Route of Stem Cell Transplantation}

The basic concept that we should know regarding the various route of stem cell transplantation is the ability of stem cells to migrate. It is already known that NSC can migrate to the site of $\mathrm{SCl}$ and differentiate into neurons and glial cells, replacing damaged cells to treat $\mathrm{SCl}$ [38], [42]. ENSCs are derived from enteric NCCs and known to be a highly migratory population [43], [44], [45]. One of the superiorities of ENSC-derived cells is using the injury as a localization cue. Because of this behavior, the ENSC localization to the injured site in $\mathrm{SCl}$ could be expected following transplantation [34].

Regarding transplantation, there are several pathways currently being used by the researcher to transplant the stem cells into the SCI model. In general, the route of stem cell transplantation can be divided into systemic and local administration. The systemic routes of stem cell transplantation are intravenous, transarterial, transnasal, and intraperitoneal. The local route of stem cell transplantation is intrathecal and intramedullary injections [45].

Intravenous administration of stem cells is not an invasive procedure and does not damage the spinal cord tissue. However, because of systemic administration, this route needs many stem cells to be administered at once to fulfill adequate migration of stem cells to the injured site [46]. Besides the intravenous route, intra-arterial administration can be used to transplant the stem cell also. The stem cells can also migrate to the injured site following this route. However, even though it is not invasive, the intravascular route also has a dangerous disadvantage, such as easy to cause blood vessel embolism.

Intranasal administration can also be used to administer stem cells to the injured spinal cord. It was reported that this route could also cause stem cells to migrate to the injured spinal cord. The administered stem cells reduce the intramedullary cavity and the recovery of hind limb motor function. However, the therapeutic effect following this procedure is not as significant as that of intrathecal administration [47]. Intraperitoneal route can also be used to transplant stem cells. A study by Ramalho et al. compared the intraperitoneal and intravenous stem cell transplantation and found that the two approaches had similar therapeutic effects on the treatment of $\mathrm{SCl}$ [48].

Local administration of stem cells to the injured part is better than systemic administration because of direct transplantation to the injured part. Local administration of stem cells of SCl treatment can be done with intramedullary and intrathecal injection [45]. Several studies reported that intramedullary injections are more effective than intravenous injection to transplant stem cells to the injured area. They also reported that intrathecal injection is less invasive than intramedullary injection. The intrathecal injection also reduces the risk of rejecting stem cells by the host's immune system [49], [50].

A study by Levi et al. evaluated the safety of intramedullary injections to treat chronic cervical and thoracic SCl. They reported no adverse events associated with cell transplantation in cervical or thoracic SCl [51]. Study by Amemori et al. compared the effects of intramedullary and intrathecal transplantation of NSC on $\mathrm{SCl}$ in rats. They found that intramedullary injection provided more prolonged survival of cells for 2 months compared to intrathecal injection. Cells injected by intrathecal injection were reported absent at the administration site or in the spinal cord tissue. They also reported that intrathecal transplantation of stem cells might have a mild therapeutic effect on $\mathrm{SCI}$ through a paracrine mechanism. However, in chronic $\mathrm{SCl}$, the longer survival time of intramedullary cells promotes regeneration of spinal cord tissue in the long term [52].

The ultrasound-guided injection can be used to assist in confirming which lamina needed to be removed to expose the post-traumatic cyst adequately. As we already know, the evidence of injury epicenter in the external or pial surface is subtle and indistinguishable. This technique helped define the caudal and rostral regions of the cyst so the appropriate location of injection could be determined [51]. Following transplantation, it was reported that ENSCs appeared to become progressively more dorsalized. This phenomenon causes almost exclusive localization of transplanted stem cells to the dorsal spinal cord [34]. The possible explanation for this may be caused by the presence of ventral neuroepithelial cells of the spinal cord. These neuroepithelial cells produce large populations 
on the ventral part of the spinal cord, which places pressure on the overlying dorsal cells. Eventually, these neuroepithelial cells progressively forcing the transplanted stem cells more dorsally [53], [54].

In chronic $\mathrm{SCl}$, the growth ability of axons through lesional tissue is significantly decreased [55]. The glial scar was developing through astrogliosis and forming well into the chronic stage of injury. Chondroitin sulfate proteoglycans (CSPGs) are elements of the extracellular matrix that formed the wall of the cystic cavity in chronic $\mathrm{SCl}$. Removing them could significantly improve outcomes following cell transplantation because increasing growth ability of stem cell to penetrate the cavity [56].

The bacterial enzyme Chondroitinase $A B C$ (ChABC) is known to have the ability to cleave CSPG moieties and degrades the impedance to plastic regeneration. A study reported that, when combined with NSC, ChABC leads to more significant cell migration and synaptic plasticity in $\mathrm{SCI}$ [57]. Another study also reported that combination of ChABC, NSPCs, and growth factor infusion increased transplanted cell migration, improved oligodendroglial remyelination, motor plasticity, and locomotor recovery [58]. Additional reports also suggested that ChABC can improve other treatment modalities and activate endogenous NSC [59], [60]. Simultaneous application of ENSCs and ChABC resulted in significant improvements in lesion histology compared to those of either treatment alone. Combined application of ChABC and ENSCs resulted in similar survival and spread of transplanted cells compared to transplant ENSCsonly. Further, dual treatments increased the number of retrograde axons crossing the injury site and reduced the amount of reactive astrogliosis in the injury zone [34].

\section{Conclusion}

Mesenteric NSC is a promising stem cell therapy to treat chronic $\mathrm{SCl}$ with low risk and easier procedure to isolate cell compare to other sources of NSC.

\section{Author Contribution}

All authors contribute equally in this article.

\section{References}

1. Cripps RA, Lee BB, Wing P, Weerts E, Mackay J, Brown D. A global map for traumatic spinal cord injury epidemiology: Towards a living data repository for injury prevention. Spinal
Cord. 2011;49(4):493-501. https://doi.org/10.1038/sc.2010.146 PMid:21102572

2. Hawryluk GW, Nakashima H, Fehlings MG. Pathophysiology and treatment of spinal cord injury. In: Winn RH, editor. Youmans and Winn Neurological Surgery. Philadelphia, PA: Elsevier; 2017. p. 2292-306

3. Metzger M, Bareiss PM, Danker T, Wagner S, Hennenlotter J, Guenther $\mathrm{E}$, et al. Expansion and differentiation of neural progenitors derived from the human adult enteric nervous system. Gastroenterology. 2009;137(6):2063-73.e4. https://doi. org/10.1053/j.gastro.2009.06.038

PMid:19549531

4. Yntema C, Hammond WS. The origin of intrinsic ganglia of trunk viscera from vagal neural crest in the chick embryo. J Comp Neurol. 1954;101(2):515-41. https://doi.org/10.1002/ cne. 901010212

PMid:13221667

5. Burns AJ, Thapar N. Neural stem cell therapies for enteric nervous system disorders. Nat Rev Gastroenterol Hepatol. 2014;11(5):317-28. https://doi.org/10.1038/nrgastro.2013.226

PMid:24322895

6. Cheng LS, Hotta R, Graham HK, Belkind-Gerson J, Nagy N, Goldstein AM. Postnatal human enteric neuronal progenitors can migrate, differentiate, and proliferate in embryonic and postnatal aganglionic gut environments. Pediatr Res. 2017;81(5):838-46. https://doi.org/10.1038/pr.2017.4

PMid:28060794

7. Amar AP, Levy ML. Pathogenesis and pharmacological strategies for mitigating secondary damage in acute spinal cord injury. Neurosurgery. 1999;44(5):1027-39; discussion 1039-40. https://doi.org/10.1097/00006123-199905000-00052

PMid:10232536

8. Hagg T, Oudega M. Degenerative and spontaneous regenerative processes after spinal cord injury. J Neurotrauma. 2006;23(3- 4):264-80. https://doi.org/10.1089/ neu.2006.23.263

PMid: 16629615

9. Rowland JW, Hawryluk GW, Kwon B, Fehlings MG. Current status of acute spinal cord injury pathophysiology and emerging therapies: Promise on the horizon. Neurosurg Focus. 2008;25(5):E2. https://doi.org/10.3171/foc.2008.25.11.e2 PMid: 18980476

10. Wilcox JT, Vawda R, Fehlings MG. Stem cell transplantation strategies after spinal cord injury. In: Lescaudron L, Rossignol $\mathrm{J}$, Dunbar GL, editors. Stem Cells and Neurodegenerative Diseases. New York: CRC Press; 2014. https://doi.org/10.1201/b16623-6

11. Giner J, Lopez CP, Hernández B, de la Riva AG, Isla A, Roda JM, et al. Update on the pathophysiology and management of syringomyelia unrelated to Chiari malformation. Neurologia (Engl Ed). 2019;34(5):318-25. https://doi.org/10.1016/j. nrleng.2018.10.004

PMid:27939111

12. Greitz D. Unraveling the riddle of syringomyelia. Neurosurg Rev 2006;29(4):251-63; discussion 264. https://doi.org/10.1007/ s10143-006-0029-5

PMid: 16752160

13. Agrawal A, Shetty MS, Pandit L, Shetty L, Srikrishna U. Posttraumatic syringomyelia. Indian J Orthop. 2007;41(4):398-400. https://doi.org/10.4103/0019-5413.37006 PMid:21139799

14. Oliveri RS, Bello S, Biering-Sorensen F. Mesenchymal stem cells improve locomotor recovery in traumatic spinal cord injury: Systematic review with meta-analyses of rat models. Neurobiol Dis. 2014;62:338-53. https://doi.org/10.1016/j.nbd.2013.10.014 


\section{PMid:24148857}

15. Tabakow P, Raisman G, Fortuna W, Czyz M, Huber J, Li D, et al. Functional regeneration of supraspinal connections in a patient with transected spinal cord following transplantation of bulbar olfactory ensheathing cells with peripheral nerve bridging. Cell Transplant. 2014;23(12):1631-55. https://doi. org/10.3727/096368914x685131 PMid:25338642

16. Zhao X, Moore DL. Neural stem cells: Developmental mechanisms and disease modeling. Cell Tissue Res. 2018;371(1):1-6.

PMid:29196810

17. Kempermann G, Song H, Gage FH. Neurogenesis in the adult hippocampus. Cold Spring Harb PerspectBiol. 2015;7(9):a018812. https://doi.org/10.1101/cshperspect.a018812 PMid:26330519

18. Heanue TA, Pachnis V. Prospective identification and isolation of enteric nervous system progenitors using Sox2. Stem Cells. 2011;29(1):128-40. https://doi.org/10.1002/stem.557 PMid:21280162

19. Burns AJ, Douarin NM. The sacral neural crest contributes neurons and glia to the post-umbilical gut: Spatiotemporal analysis of the development of the enteric nervous system. Development. 1998;125(21):4335-47. https://doi.org/10.1242/ dev.125.21.4335

\section{PMid:9753687}

20. Burzynski G, Sheperd IT, Enomoto H. Genetic model system studies of the development of the enteric nervous system, gut motility and Hirschprung's disease. Neurogastroenterol Motil. 2009;21(2):113-27. https://doi. org/10.1111/j.1365-2982.2008.01256.x

PMid:19215589

21. Schafer $\mathrm{KH}$, Ginneken CV, Copray S. Plasticity and neural stem cells in the enteric nervous system. Anat Rec (Hoboken). 2009;292(12):1940-52. https://doi.org/10.1002/ar.21033 PMid:19943347

22. Giaroni C, De Ponti F, Cosentino M, Lecchini S, Frigo G. Plasticity in the enteric nervous system. Gastroenterology. 1999;117(6):1438-58. https://doi.org/10.1016/ s0016-5085(99)70295-7

PMid:10579986

23. Furness JB. The enteric nervous system and neurogastroenterology. Nat Rev Gastroenterol Hepatol. 2012;9(5):286-94. https://doi.org/10.1038/nrgastro.2012.32 PMid:22392290

24. Young KM, Merson TD, Sotthibundhu A, Coulson EJ, Bartlett PF. P75 neurotrophin receptor expression defines a population of BDNF-responsive neurogenic precursor cells. J Neurosci. 2007;27(19):5146-55. https://doi.org/10.1523/ jneurosci.0654-07.2007

PMid:17494700

25. Amador-Arjona A, Cimadamore F, Huang CT, Wright R, Lewis S, Gage $\mathrm{FH}$, et al. SOX2 primes the epigenetic landscape in neural precursors enabling proper gene activation during hippocampal neurogenesis. Proc Natl Acad Sci USA. 2015;112(15):E1936- 45. https://doi.org/10.1073/pnas.1421480112

PMid:25825708

26. Graham V, Khudyakov J, Ellis P, Pevny L. SOX2 functions to maintain neural progenitor identity. Neuron. 2003;39(5):749-65. https://doi.org/10.1016/s0896-6273(03)00497-5 PMid:12948443

27. Belkind-Gerson J, Carreon-Rodriguez A, Benedict LA, Steiger C, Pieretti A, Nagy N, et al. Nestin-expressing cells in the gut give rise to enteric neurons and glial cells.
Neurogastroenterol Motil. 2013;25(1):61-9.e7. https://doi. org/10.1111/nmo.12015

PMid:22998406

28. Park D, Xiang AP, Mao FF, Zhang L, Di CG, Liu XM, et al. Nestin is required for the proper self-renewal of neural stem cells. Stem Cells. 2010;28(12):2162-71. https://doi.org/10.1002/stem.541 PMid:20963821

29. Bernal A, Arranz L. Nestin-expressing progenitor cells: Function, identity, and therapeutic implications. Cell Mol Life Sci. 2018;75(12):2177-95. https://doi.org/10.1007/ s00018-018-2794-z

PMid:29541793

30. Svendsen CN, Bhattacharyya A, Tai YT. Neuron from stem cells: Preventing an identity crisis. Nat Rev Neurosci. 2001;2(11):831 - 4. https://doi.org/10.1038/35097581 PMid:11715059

31. Binder E, Natarajan D, Cooper J, Kronfli R, Cananzi M, Delalande JM, et al. Enteric neurospheres are not specific to neural crest cultures: Implications for neural stem cell therapies. PLoS One. 2015;10(3):e0119467. https://doi.org/10.1371/ journal.pone. 0119467

PMid:25799576

32. CooperJE, McCann CJ, Natarajan D, Choudhury S, Boesmans W, Delalande JM, et al. In vivo transplantation of enteric neural crest cells into mouse gut; engraftment, functional integration and long-term safety. PLoS One. 2016;11(1):e0147989. https:// doi.org/10.1371/journal.pone.0147989

PMid:26824433

33. McConalogue K, Furness JB. Gastrointestinal neurotransmitters. Baillieres Clin Endocrinol Metab. 1994;8(1):51-76. PMid:7907863

34. Jevans BS. Biology and therapeutic potential of enteric nervous system stem cells for spinal cord injury. In: Stem Cells and Regenerative Medicine. United Kingdom: UCL Great Ormond Street Institute of Child Health; 2017.

35. Gershon MD, Tack J. The serotonin signaling system: From basic understanding to drug development for functional GI disorders. Gastroenterology. 2007;132(1):397-414. https://doi. org/10.1053/j.gastro.2006.11.002

PMid: 17241888

36. Swank HA, Eshuis EJ, van Berge Henegouwen MI, Bemelman WA. Short-and long-term results of open versus laparoscopic appendectomy. World J Surg. 2011;35(6):1221-6; discussion 1227-8. https://doi.org/10.1007/s00268-011-1088-5 PMid:21472367

37. Schafer K--H, Micci MA, Pasricha PJ. Neural stem cell transplantation in the enteric nervous system: Roadmaps and roadblocks. Neurogastroenterol Motil. 2009;21(2):103-12. https://doi.org/10.1111/j.1365-2982.2008.01257.x PMid: 19215588

38. Almond S, Lindley RM, Kenny SE, Connell MG, Edgar DH. Characterisation and transplantation of enteric nervous system progenitor cells. Gut. 2007;56(4):489-96. https://doi. org/10.1136/gut.2006.094565 PMid: 16973717

39. Heanue TA, Pachnis V. Enteric nervous system development and Hirschprung's disease: Advance in genetic and stem cell studies. Nat Rev Neurosci. 2007;8(6):466-79. https://doi. org/10.1038/nrn2137 PMid: 17514199

40. Schrenk S, Schuster A, Klotz M, Schleser F, Lake J, Heuckeroth RO, et al. Vascular and neural stem cells in the gut: Do they need each other? Histochem Cell Biol. 2015;143(4):397-410. https://doi.org/10.1007/ 
s00418-014-1288-9

PMid:25371326

41. Hagl Cl, Heumuller-Klug S, Wink E, Wessel L, Schafer KH. The human gastrointestinal tract, a potential autologous neural stem cell source. PLoS One. 2013;8(9):e72948. https://doi. org/10.1371/journal.pone.0072948

PMid:24023797

42. Takeuchi H, Natsume A, Wakabayashi T, Aoshima C, Shimato S, Ito $\mathrm{M}$, et al. Intravenously transplanted human neural stem cells migrate to the injured spinal cord in adult mice in an SDF-1and HGF-dependent manner. Neurosci Lett. 2007;426(2):69-74. https://doi.org/10.1016/j.neulet.2007.08.048

PMid: 17884290

43. Bronner-Fraser M. Neural crest cell formation and migration in the developing embryo. FASEB J. 1994;8(10):699-706. https:// doi.org/10.1096/fasebj.8.10.8050668

PMid:8050668

44. McLennan R, Schumacher LJ, Morrison JA, Teddy JM, Ridenour DA, Box AC, et al. Neural crest migration is driven by a few trailblazer cells with a unique molecular signature narrowly confined to the invasive front. Development. 2015;142(11):2014- 25. https://doi.org/10.1242/dev.117507 PMid:25977364

45. Oh SK, Jeon SR. Current concept of stem cell therapy for spinal cord injury: A review. Korean J Neurotrauma. 2016;12(2):40-6. https://doi.org/10.13004/kjnt.2016.12.2.40

PMid:27857906

46. Gao L, Peng Y, Xu W, He P, Li T, Lu X, Chen G. Progress in stem cell therapy for spinal cord injury. Stem Cells Int. 2020;2020:2853650. https://doi.org/10.1155/2020/2853650 PMid:33204276

47. Ninomiya K, Iwatsuki K, Ohnishi Y-I, Ohkawa T, Yoshimine T. Intranasal delivery of bone marrow stromal cells to spinal cord lesions. J Neurosurg Spine. 2015;23(1):111-9. https://doi. org/10.3171/2014.10.spine14690 PMid:25840039

48. Ramalho BD, de Almeida FM, Sales CM, de Lima S, Martinez AM. Injection of bone marrow mesenchymal stem cells by intravenous or intraperitoneal routes is a viable alternative to spinal cord injury treatment in mice. Neural Regen Res. 2018;13(6):1046-53. https://doi. org/10.4103/1673-5374.233448 PMid:29926832

49. Bakshi A, Hunter C, Swanger S, Lepore A, Fischer I. Minimally invasive delivery of stem cells for spinal cord injury: Advantages of the lumbar puncture technique. J Neurosurg Spine. 2004;1(3):330-7. https://doi.org/10.3171/spi.2004.1.3.0330 PMid:15478372

50. Paul C, Samdani AF, Betz RR, Fischer I, Neuhuber B. Grafting of human bone marrow stromal cells into spinal cord injury: A comparison of delivery methods. Spine (Phila Pa 1976). 2009;34(4):328-34. https://doi.org/10.1097/brs.0b013e31819403ce PMid: 19182705

51. Levi AD, Okonkwo DO, Park P, Jenkins AL $3^{\text {rd }}$, Kurpad SN,
Parr AM, et al. Emerging safety of intramedullary transplantation of human neural stem cells in chronic cervical and thoracic spinal cord injury. Neurosurgery. 2018;82(4):562-75. https://doi. org/10.1093/neuros/nyx250

PMid:28541431

52. Amemori T, Ruzicka J, Romanyuk N, Jhanwar-Uniyal $M$, Sykova E, Jendelova P. Comparison of intraspinal and intrathecal implantation of induced pluripotent stem cell-derived neural precursors for the treatment of spinal cord injury in rats. Stem Cell Res Ther. 2015;6(1):257. https://doi.org/10.1186/ s13287-015-0255-2

PMid:26696415

53. Bronner-Fraser M, Fraser SE. Differentiation of the vertebrate neural tube. Curr Opin Cell Biol. 1997;9(6):885-91.

PMid:9425355

54. McConnell JA, Sechrist JW. Identification of early neurons in the brainstem and spinal cord: I. An autoradiographic study in the chick. J Comp Neurol. 1980;192(4):769-83. https://doi. org/10.1002/cne.901920410

PMid:7419754

55. Kerschensteiner M, Schwab ME, Lichtman JW, Misgeld T. In vivo imaging of axonal degeneration and regeneration in the injured spinal cord. Nat Med. 2005;11(5):572-7. https://doi. org/10.1038/nm1229

PMid: 15821747

56. Bradbury EJ, Moon LDF, Popat RJ, King VR, Bennett GS, Patel PN, et al. Chondroitinase ABC promotes functional recovery after spinal cord injury. Nature. 2002;416(6881):636- 40. https:// doi.org/10.1038/416636a

PMid:11948352

57. Ikegami $\mathrm{T}$, Nakamura $\mathrm{M}$, Yamane J, Katoh $\mathrm{H}$, Okada $\mathrm{S}$, Iwanami A, et al. Chondroitinase ABC combined with neural stem/ progenitor cell transplantation enchances graft cell migration and outgrowth of growth-associated protein-43-positive fibers after rat spinal cord injury. Eur J Neurosci. 2005;22(12):3036- 46. https://doi.org/10.1111/j.1460-9568.2005.04492.x PMid: 16367770

58. Karimi-Abdolrezaee S, Eftekharpour E, Wang J, Schut D, Fehlings MG. Synergistic effects of transplanted adult neural stem/progenitor cells, chondroitinase, and growth factors promote functional repair and plasticity of the chronically injured spinal cord. J Neurosci. 2010;30(5):1657-76. https://doi. org/10.1523/jneurosci.3111-09.2010

PMid:20130176

59. Karimi-Abdolrezaee S, Schut D, Wang J, Fehlings MG Chondroitinase and growth factors enhance activation and oligodendrocyte differentiation of endogenous neural precursor cells after spinal cord injury. PLos One. 2012;7(5):e37589. https://doi.org/10.1371/journal.pone.0037589

PMid:22629425

60. Garcia-Alias G, Barkhuysen S, Buckle M, Fawcett JW. Chondroitinase $A B C$ treatment opens a window of opportunity for task-specific rehabilitation. Nat Neurosci. 2009;12(9):1145- 51. https://doi.org/10.1038/nn.2377

PMid: 19668200 